\title{
市場から得た深溝玉軸受ボール内部の白色組織の特徵
}

\author{
宮川 進*1，西村 貴郎*2，中澤 聖*3，塩谷 延広*2
}

\section{Characterisation of white etching area in a ball of deep groove ball bearing obtained from the market}

\author{
Susumu MIYAKAWA ${ }^{* 1}$, Yoshiro NISHIMURA ${ }^{* 2}$, Satoru NAKAZAWA ${ }^{* 3}$ and Nobuhiro SHIOYA ${ }^{* 2}$ \\ ${ }^{{ }_{1},{ }^{*} 2}$ Material Eng. R\&D Dept of DENSO CORPORATION \\ 1-1 Showa-cho, Kariya-Shi, Aichi, 448-8661 Japan \\ ${ }^{* 3}$ DENSO INTERNATIONAL AMERICA, INCORPORATED \\ 24777 Denso Dr, Southfield, MI 48033 USA
}

Received: 18 January 2018; Revised: 12 June 2018; Accepted: 14 November 2018

\begin{abstract}
White etching area may be recoginized at the flaking part of a rolling bearing on which high contact stress of several GPa is applied repeatedly. Up to now, there have been less studies of the white etching area of a ball than that of inner and outer rings. In this study, as part of the flaking mechanism explication of white etching area in a ball of deep groove ball bearing, the form, the structure and chemical composition of white etching area were investigated. The form of the white etching area of a ball is mostly identical to the form of the white etching area of the inner ring and the outer ring. The white etching area of the ball is formed from the ferrite grains of tens of $\mathrm{nm}$ and is mostly identical to the white etching area of inner and outer rings. The carbon density of white etching area is higher than the carbon density of the matrix, and much carbon exists at the grain boundary of the ferrite grains of tens of nm. These results of carbon are mostly identical to the results of the carbon of the white etching area of cylindrical roller thrust bearing races.
\end{abstract}

Keywords : White etching area, Rolling contact fatigue, TEM, 3DAP, Ferrite of tens of nm, Carbon

\section{1. 緒言}

1980 年代の国内において, 自動車電装補機部品の高速化・高出力化の対応の一手段として, 電装補機部品の駆 動ベルトが従来の V ベルトから伝達能力の高いポリVベルトへ変更されるようになった. この変更に対して, 計 算寿命より短寿命となる白色組織（WEA : White Etching Area）を伴った白色き裂（WEC: White Etching Crack）に よる白色はく離（WSF : White Structure Flaking）が電装補機部品用転がり軸受である深溝玉軸受の内外輪で散発 するようになった．数多くの研究がなされ，この WSF メカニズムに関していくつかの説が提案されている. 大 別して，複雑な応力状態が影響するとした説（柴田他，1996，植田他，2002）と転がり軸受に侵入した水素が影 響するとした説（Tamada and Tanaka，1996，平岡，2008）がある. 前者は軌道面内部に接触面圧によって生じる

No.18-00034 [DOI:10.1299/transjsme.18-00034], J-STAGE Advance Publication date : 22 November, 2018

*1 正員, (株) デンソー（干448-8661 愛知県刈谷市昭和町 1-1）

*2 (株) デンソー

*3 DENSO INTERNATIONAL AMERICA, INCORPORATED (24777 Denso Dr, Southfield, MI 48033 USA)

E-mail of corresponding author:susumu_miyakawa@denso.co.jp 
応力に曲げ・振動・衝撃およびすべりによる接線力により生じる応力が加わった複雑な応力場の影響で WSF が 発生すると考えられている. 後者は転がり接触によって潤滑油や水が分解された時に発生する水素が浸入, 拡散 するとともに，接触面圧の繰返しにより軌道面内部に微小き裂が発生し，そのき裂が早期に連結，形成したき裂 を起点としてWEC を伴ったWSF が発生すると考えられている (平岡, 2008). 更には, WEA の透過型電子顕微 鏡（TEM : Transmission Electron Microscope）による組織観察の結果, WEA は数 10nm のフェライト結晶粒であ ることを明らかにしている（柴田他, 1996, 植田他, 2002).

近年，国外において，風力タービンの大型化にともなってギヤボックスに用いられている転がり軸受に WSF が発生するようになり, 数多くの研究がなされている. 使用中にはく離した風力タービンギヤボックスの円筒こ ろ軸受の内輪の断面組織観察にて, 介在物と WEC の発生との関係に関して検討を加えた研究事例が報告されて いる (Bruce et al., 2015). 水素をチャージした深溝玉軸受と水素をチャージしていないアンギュラー玉軸受の内 輪の転がり疲労試験（RCF : Rolling Contact Fatigue）過程における一連の断面組織観察にて, 水素と接触面圧の組 織変化に及ぼす影響に関して検討を加えた研究事例が報告されている（Ooi et al., 2017）。水素チャージをしてい ない円筒ころスラスト軸受のころの RCF 過程における一連の断面組織観察にて, 介在物と WEC の発生の関係に 関して検討を加えた研究事例が報告されている（Richardson et al., 2018）。この事例では，レースよりも円筒ころ に WSF が発生する原因として介在物の清浄度がレースよりも円筒ころの方が低いことを挙げている. 又, 水素 をチャージしていない円筒ころスラスト軸受のレースとアンギュラー玉軸受の内輪の WEC 形成の主要なトライ ボロジー要因として表面滑りエネルギークライテリア ( $\mathrm{P} \Delta \mathrm{V}$ :surface sliding energetic criteria, $\mathrm{P}$ : contact pressure, $\Delta$ V : slip velocity) に関して検討を加えた研究事例が報告されている (Ruellan et al., 2015). この分野においても, WEA の TEM による組織観察がなされており, WEA がナノ結晶のフェライト組織であることが確認されいる. これに加えて, 水素をチャージしていない円筒ころスラスト軸受のレースに生成した WEA に関して 3 次元アト ムプローブ（3DAP : 3 Dimensional Atom Probe）を用いた化学成分分析がなされ，10nm の等軸のフェライト結晶 粒の粒内よりも粒界に炭素 C が分離して存在していることを明らかにしている（Danielsen et al., 2017）.

先に示した自動車電装補機部品用転がり軸受である深溝玉軸受の内外輪では，粘度の高い基油の採用などのグ リース改良によってWSFの発生防止がほぼ出来るようになってきたが，その後判明したことはWSFがボールに おいて散発しているということである。ボールは自由に回転することができるためにストレスがボール表面で分 散され，ストレスが絶えず同一点で負荷される内外輪に比較して疲労損傷が少ないにも関わらず WSF が内外輪 とほぼ同一の短寿命で発生している. 水素をチャージしていない複列アンギュラー玉軸受のボールの RCF 過程に おける断面組織観察にて, 黒色組織（DER : Dark Etching Region）の形成メカニズムに関して検討を加えた研究事 例が報告されている（Šmelıva et al., 2017）が，ボールの WSF を取上げた研究事例の報告は無い.

本研究は, ボールの WSF メカニズム解明の一環として, 市場から得た短寿命のボールに生じた WEA に関して マクロからナノスケールの観察技術を用いて形態，組織および化学成分を検討したので報告する.

\section{2. 実験方法および実験条件}

\section{$2 \cdot 1$ 軸受および材料}

市場で運転されていた自動車用電装補機部品より転がり軸受である深溝玉軸受を取外した。この電装補機部品 が取り付いていた自動車の走行距離は数万 $\mathrm{km}$ であった。運転時のベルトによる荷重は $1000 \mathrm{~N}$ 程度であり, 回転 数は平均 $4000 \sim 5000 \mathrm{rpm}$ である. 使用環境は大気中で, 使用温度は平均 $100^{\circ} \mathrm{C}$ 程度である. 深溝玉軸受は次の 2 種類である. 呼び番号 6202 (外径 $35 \mathrm{~mm} \times$ 内径 $15 \mathrm{~mm} \times$ 幅 $11 \mathrm{~mm}$ ，ボールの直径 $15 / 64$ インチ）と呼び番号 6302 (外 径 $42 \mathrm{~mm} \times$ 内径 $15 \mathrm{~mm} \times$ 幅 $13 \mathrm{~mm}$ ，ボールの直径 5/16 インチ) である．潤滑はグリース潤滑であり，エーテル系合 成油を基油とし，ジウレアを増ちょう剤としている.

ボールの材料は高炭素クロム軸受鋼 SUJ2 であり, 焼入れ焼戻しの熱処理をしている. 表面下 $0.15 \mathrm{~mm}$ でのビッ カース硬度は約 HV825 で，X線による残留オーステナイト量測定の結果は約 7\%であった。 なお, $(\mathrm{Fe}, \mathrm{Cr})_{3} \mathrm{C}$ の球 状炭化物（瀬戸，1999）は，母相に均一に分布している. 


\section{$2 \cdot 2$ 分析機器}

次の各種分析機器を用いた. 光学影微鏡（OM：Optical Microscope オリンパス社製 GX51）による形態観察条 件は 100〜400 倍である. 走查型電子顕微鏡（FIB/SEM : Focused Ion Beam System /Scanning Electron Microscope FEI 社製 NOVA200）による外観と形態観察条件は 25〜1000 倍である. 透過型電子顕微鏡（TEM 日立製作所製 H-800 FE-TEM 日立製作所製 HF-2000） による組織観察条件は 30000～1500000 倍である．電子線マイクロプローブア ナライザー (EPMA : Electron Probe Micro Analyzer 日本電子社製 JXA-8100） による形態観察条件は加速電圧 $15 \mathrm{kV}$ で倍率 250 3000 倍, 化学成分分析条件は加速電圧 $15 \mathrm{kV}$ ・電流值 $50 \mathrm{nA}$ で白色組織のビーム径は直径〜 $1 \mu \mathrm{m}$ で,

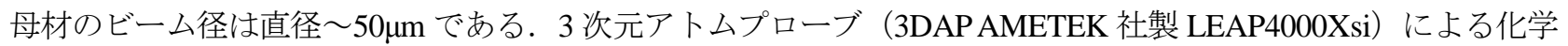
成分分析条件はレーザー波長 $355 \mathrm{~nm} ・$ レーザーパワー20pJ・パルスレート $500 \mathrm{kHz} ・$ 蒸発レート $0.2 \%$ 試料温度 50K $\left(-223^{\circ} \mathrm{C}\right)$ である.

\section{3. 実験結果と考察}

\section{$3 \cdot 1$ 走査型電子顕微鏡 SEM を用いたはく離部の外観観察結果}

深溝玉軸受に用いられているボール全てにはく離が認められているわけではなく，1 個か 2 個がはく離する場 合が大多数である.5/16 インチのボールに生じたはく離部の SEM を用いた観察結果を図 1 に示寸. はく離部は 概略円形であり, 直径 1 2 $\mathrm{mm}$ 程度である.このはく離部は 2 つ円形が隣接して存在しているように観察され る. はく離の外表面は破片等との干渉によると思われる潰れが認められ，はく離過程を示す破面は残存していな い.

\section{$3 \cdot 2$ 光学顕微鏡 OM を用いた WEC 形態観察結果}

樹脂埋めした図 1 に示寸はく離したボールを断面研磨後にナイタール腐食した. はく離以外の内部に観察され たWEAを伴った WEC を図 2 に示す. 次の（1）〜（3）のような形態が観察される.（1）複数の WECが混在し てネットワーク化した大きな WEC が軌道面内部の広範囲に観察される. WEA がき裂面上に認められる部分と認 められない部分がある.（2）このWEC は白色組織変化の他の形態であるバンド状のホワイトバンドや蝶の羽状 のバタフライとは異なった不規則形状である（平岡，2008）。（3）軌道面内部 $0.1 〜 0.25 \mathrm{~mm}$ 深さあたりに，深さ 方向へ枝垂柳状に観察される.

\section{$3 \cdot 3$ 走查型電子顕微鏡 SEM を用いた WEA の形態観察結果}

図 2 の WEA の SEM 観察結果を図 3 に示寸. 次の（1）～（5）の形態が観察される，（1）母相と WEA の境界 は明瞭である.（2）WEA 内部に筋状の模様が観察される．筋状の模様を赤枠内に拡大して示寸．（3）WEA 内に ボイドが観察される.（4）母相には直径 $1 \mu \mathrm{m}$ 程度の球状炭化物が認められるが，WEA 内ではほとんど消失して いる.（5）WEA はミクロき裂と共存している.

上記 $3 \cdot 2$ と $3 \cdot 3$ で述べた形態は従来の内外輪軌道面内部に生じた白色組織の形態（柴田他, 1996, 植田他, 2002）とほぼ同一である.

筋状の模様には筋状方向に変形を受けた炭化物が観察される．これは局所塑性変形のために生じたと考えられ る. 球状炭化物がほとんで消失しているのは局所変形の下で高転位密度の発達によって分解したものと思われる. 円筒ころ軸受の内輪に発生したバタフライの場合で変形を受けた炭化物の観察結果が報告されている（Bruce et al., 2015). 又，ボイドは十分に分解出来ずに残留した球状炭化物が研磨時等に脱落した跡と思われる. 水素于ャ ージした深溝玉軸受の内輪に発生した WEA において同様なボイドが認められている (Ooi et al., 2017).上記のよ うにWEA がき裂面上に認められる部分と認められない部分があること，母相と WEA の境界が明瞭なことおよ び局所塑性変形が認められることより，WEA は RCF 中の数 GPa の高い繰返し接触面圧に対応した内部応力によ るき裂同士の摩擦により生じたものと思われる，風力タービンに関する研究事例において，WEA 形成メカニズ ムとしてき裂同士の摩擦が提唱されている（Richardson et al., 2018）. 


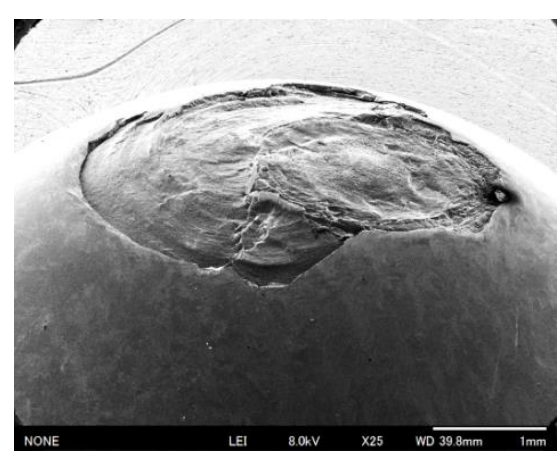

Fig. 1 Outer appearance of the flaking of a ball

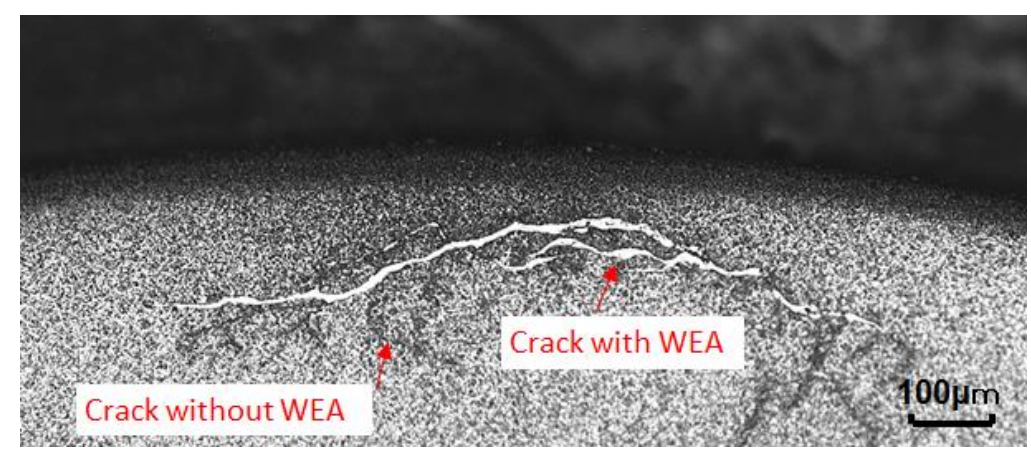

Fig. 2 Optical microscope photo of WEC

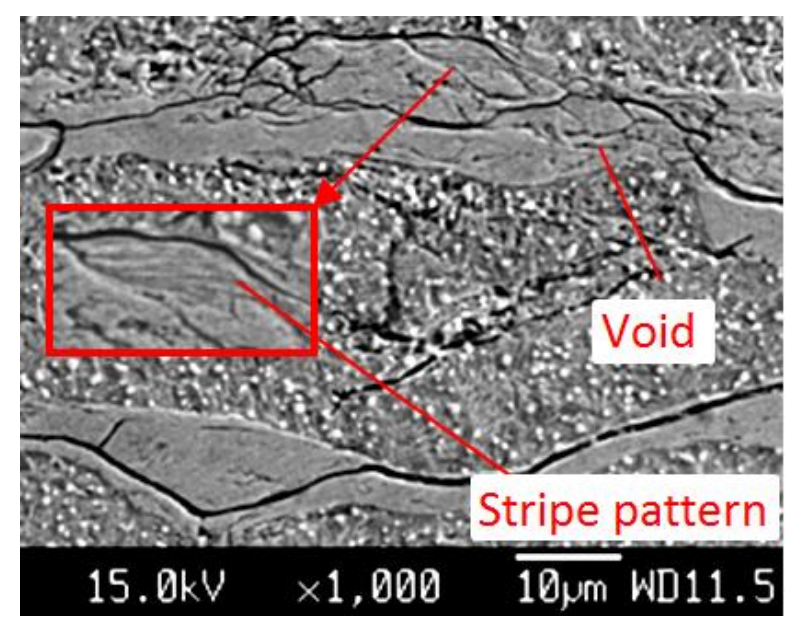

Fig. 3 SEM photo of WEA

\section{3-4 透過電子顕微鏡 TEM を用いた WEA の組織観察結果}

15/64 インチのボールにおいて，はく離付近で観察された WEA の OM 写真を図 4 に示す. 図 5 に TEM 観察結 果を示す．図 5(a)は母相の焼戻しラスマルテンサイト組織と WEA の境界の TEM 写真である. 母相と WEA の境 界は明瞭である.WEA は図 5(b)に示すように数 $10 \mathrm{~nm}$ 程度の粒状組織となっている. 150 万倍まで拡大して観察 したが，この粒状組織内や粒界に析出物は認められなかった。

WEA の電子線回折パターンを図 6 に示す. 回折スポットのつらなったリング状を呈していることより，WEA はランダムに配向していることが分かる. 回折リングの径を格子間隔が既知の Si を基準として較正した結果を表 1 に示す. 白色組織の格子定数は $\alpha-\mathrm{Fe}$ (フェライト)とほぼ一致した.

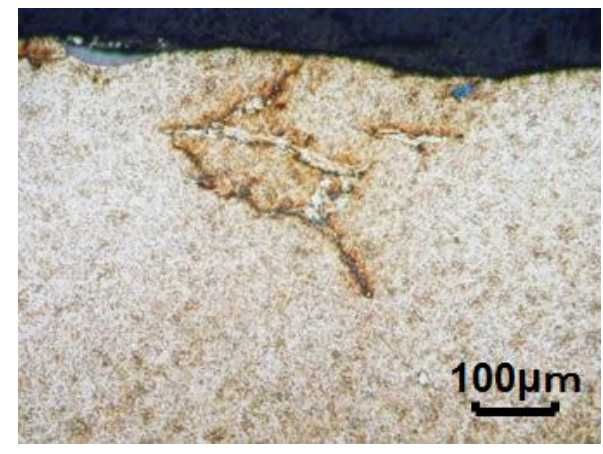

(a) Low magnification

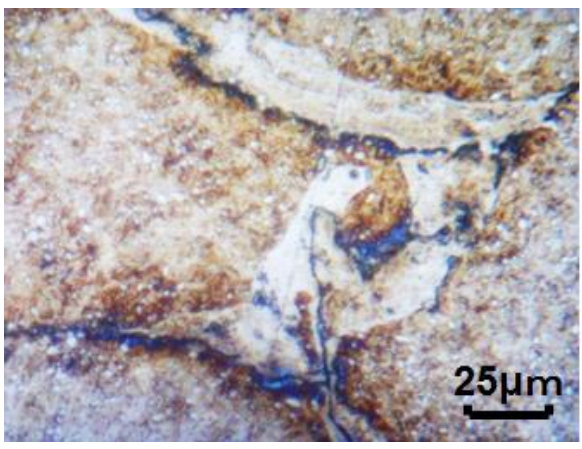

(b) High magnification

Fig. 4 Optical microscope photo of WEA 


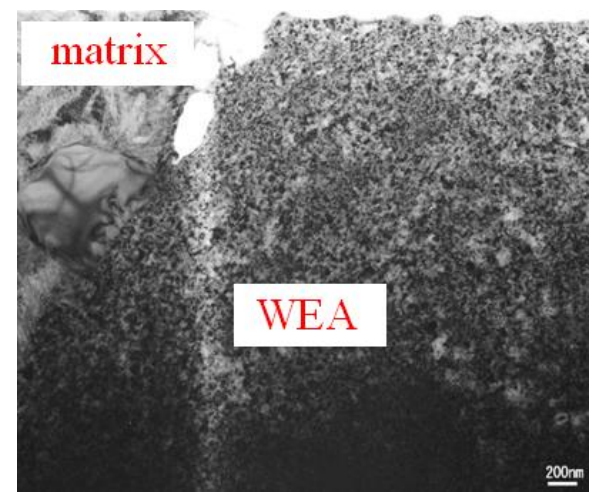

(a) A boundary between matrix and WEA

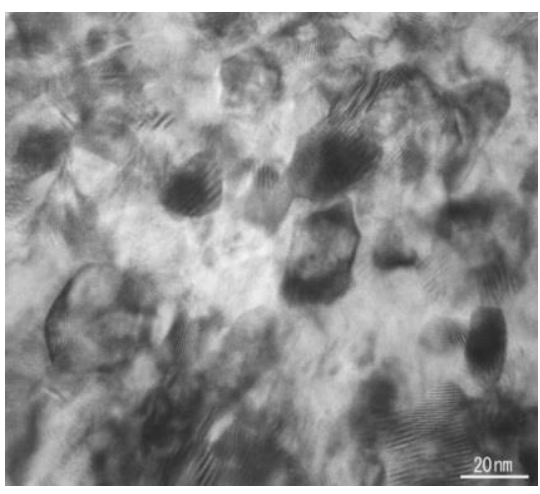

(b) WEA

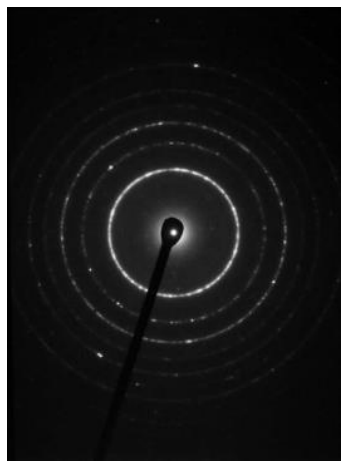

Fig. 6 Selected area diffraction pattern obtained from WEA

Table 1 Quantitative analysis of lattice constant
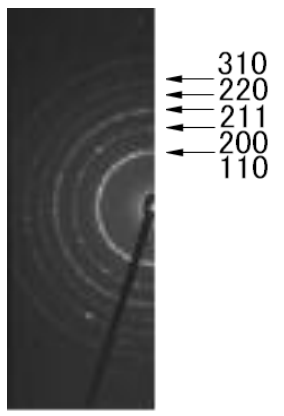

\begin{tabular}{c|c|c|c|c}
\hline \hline \multicolumn{3}{c|}{ Analysis } & \multicolumn{2}{c}{$\alpha-F e$} \\
\hline Point & Distance (mm) & $\mathrm{d}(\AA)$ & $\mathrm{d}(\AA)$ & $\mathrm{h} \mathrm{k} 1$ \\
\hline r1 & 9.50 & 2.0316 & 2.0268 & 110 \\
\hline r2 & 13.40 & 1.4403 & 1.4332 & 200 \\
\hline r3 & 16.50 & 1.1697 & 1.1702 & 211 \\
\hline r4 & 19.00 & 1.0158 & 1.0134 & 220 \\
\hline r5 & 21.35 & 0.9040 & 0.9064 & 310 \\
\hline
\end{tabular}

ボールに生じた WEA の組織は従来の内外輪軌道面内部に生じた WEA の組織（柴田他，1996，植田他，2002） とほぼ同一である.

\section{$3 \cdot 5$ 電子線マイクロプローブアナライザ一EPMA を用いた WEA の化学成分分析結果}

図 2 に示した WEA と母相を EPMA を用いて定性分析および半定量分析を行った. 分析を行った個所を赤丸で 図 7 に示す. 定性分析の結果によれば，母相と WEA ともに Feが主成分で C, O , Si， Cr, Mn が検出されたが， 高炭素クロム軸受鋼の規格值として定められた材料成分以外の元素は検出されていない. 半定量分析の結果を表 2 に示寸. WEA と母相の組成比に大差は認められないが, WEA 1 のC濃度は母相と比較して増加しており WEA 2 の C 濃度は母相と比較して低下している. Cr 濃度の場合は, WEA 1, WEA 2 と母相で大差ない結果となってい る.

WEA と母相の化学成分分析に EPMA を用いた事例を見ると, 線分析の結果により WEA の C 濃度は母相より も低下しているとの報告事例がある（植田他，2002）。一方，線分析の結果によりWEA と母相で差は認められず $\mathrm{C}$ 濃度は約 $1 \mathrm{wt} \%$ と推定している報告事例がある.この事例によれば, 他の部分の面分析では WEA の C 濃度が母 相と比べて増加している部分もあり，混在しているとのことである（柴田他，1996）.

今回の EPMA を用いた C 濃度分析結果はこれらの報告事例内容と同様な傾向である. 

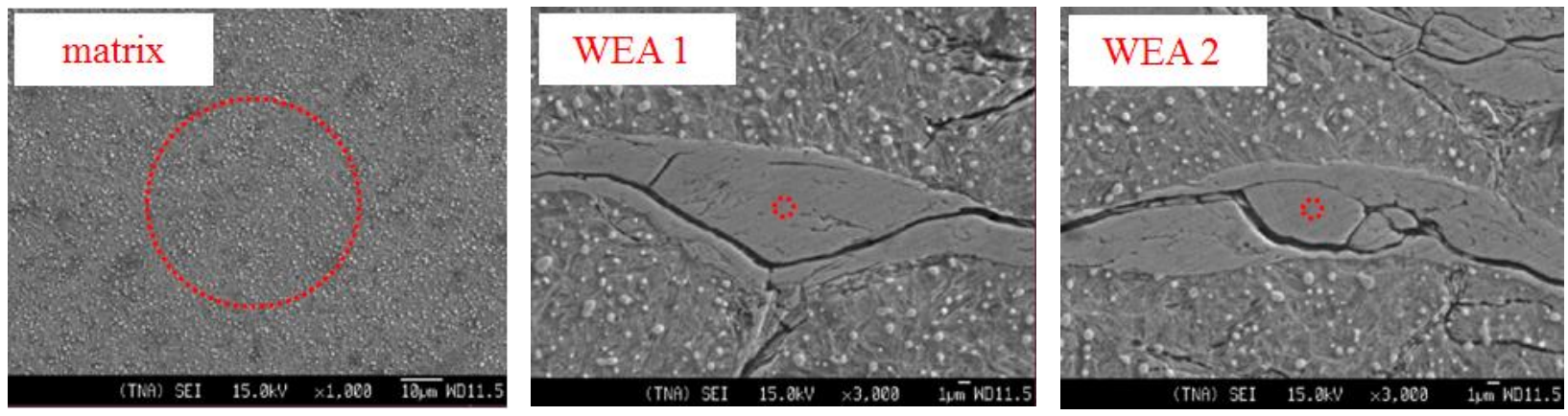

Fig. 7 Positions of EPMA analysis

Table 2 Detected chemical compositions

\begin{tabular}{c|c|c|c|c|c|c}
\hline \multirow{2}{*}{ Positions } & \multicolumn{5}{|c}{ Chemical compositions (wt\%) } \\
\cline { 2 - 7 } & $\mathrm{C}$ & $\mathrm{O}$ & $\mathrm{Si}$ & $\mathrm{Cr}$ & $\mathrm{Mn}$ & $\mathrm{Fe}$ \\
\hline WEA 1 & 5 & 1 & 0.3 & 1.6 & 0.5 & 91.5 \\
\hline WEA 2 & 2 & 1 & 0.3 & 1.7 & 0.5 & 94.0 \\
\hline matrix & 3 & 1 & 0.3 & 1.7 & 0.5 & 93.5 \\
\hline
\end{tabular}

\section{$3 \cdot 63$ 次元アトムプローブ 3DAP を用いた WEA の化学成分分析結果}

\section{$3 \cdot 6 \cdot 1$ はく離部付近の WEA}

図 2 に示したWEA に対して3DAP を用いて分析を行った. 図 8 に示すように分析個所は母相, WEAおよび WEA と母相の境界の 3 か所である. 図 9 に, 試験片の一例として, WEA と母相の境界における試験片を示す. 試験片の先端は表面から 200～300nm 程度深い部分となり，その試験片の直径数 $10 \mathrm{~nm}$ 程度の円柱領域よりデー ターを得ている.

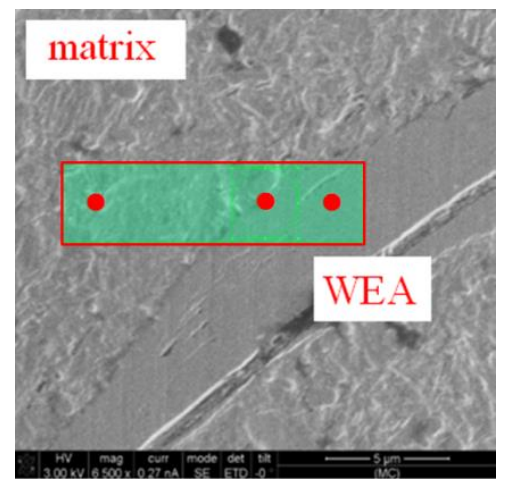

Fig. 8 Positions of 3DAP analysis

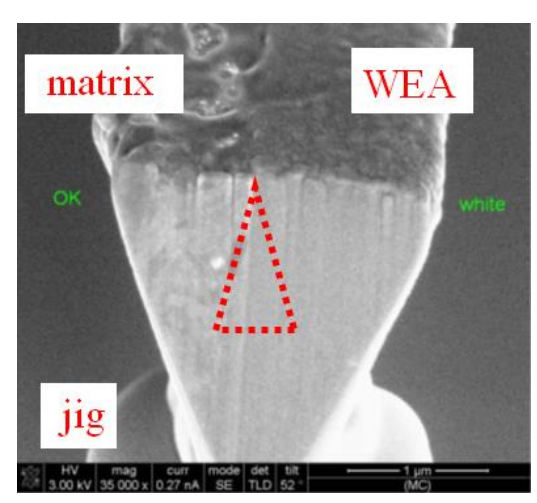

(a) Prepared triangular prism using FIB on the jig

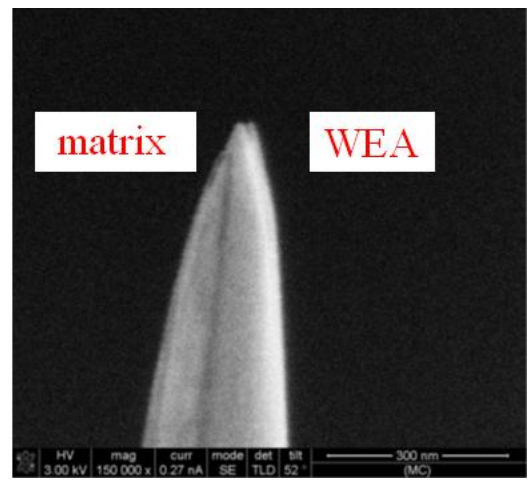

(b) Needle-shaped specimen

Fig. 9 Specimen between matrix and WEA 
試験片製作方法の概略を示す. 図 8 に示した 3 箇所の分析位置を含むように三角柱形状を収束イオンビーム (FIB : Focused Ion Beam System) にて掘り取る. 三角柱形状の分析位置に相当寸る部分を剣山状の試料台に固定・ 切断する. 図 9 の(a)はWEA と母相の境界における三角柱形状が試料台に固定されている状態を示している. そ の後, Ga ビームにて破線状の針状の試験片のように削り，図 9 の(b)のような針状の試験片を得ている.

上記で得られた試験片の分析方法の概略を次に示す．針状の試験片に正電圧をかけると試験片最先端で高電界 になり, 電解蒸発現象が発生する. 電解蒸発とは試験片表面の中性子原子が+イオン化し表面から脱離する現象 で, 電解蒸発したイオンは 2 次元検出器により原子配列が特定される. 又, 検出器に到達するまでの飛行時間か らイオン種が同定される.このようにして個々に検出されたイオンを深さ方向に連続的に検出し, 検出された順 番にイオンを並べることで 3 次元の原子分布を得ている.

図 10 (a)(b)にWEA と母相の境界の全原子の 3 次元原子像と C のみの 3 次元原子像を示寸. 図 10 (c)には母相と WEA の境界の各材料成分の濃度分布を示す．針状の試験片の軸に対して垂直方向の線分析結果である．母相に 対してWEA では C 濃度が大幅に増加している. また Cr 濃度も増加している. その他の成分は母相と WEA で大 差ない. なお， 3 次元原子像や分析結果より，分析した試験片内に球状炭化物を含んでいないことは明らかであ る.

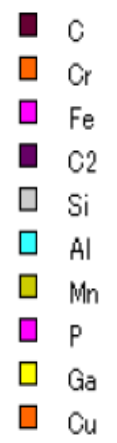

(a) Three-dimensional image of the detected chemical compositions

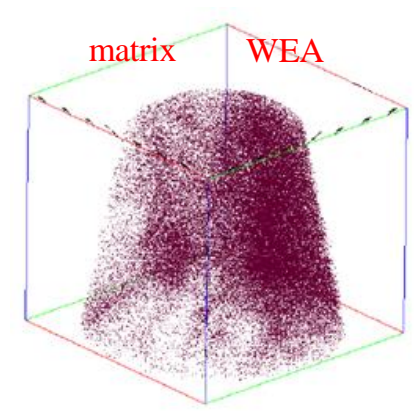

(b) Three-dimensional image of the detected carbon

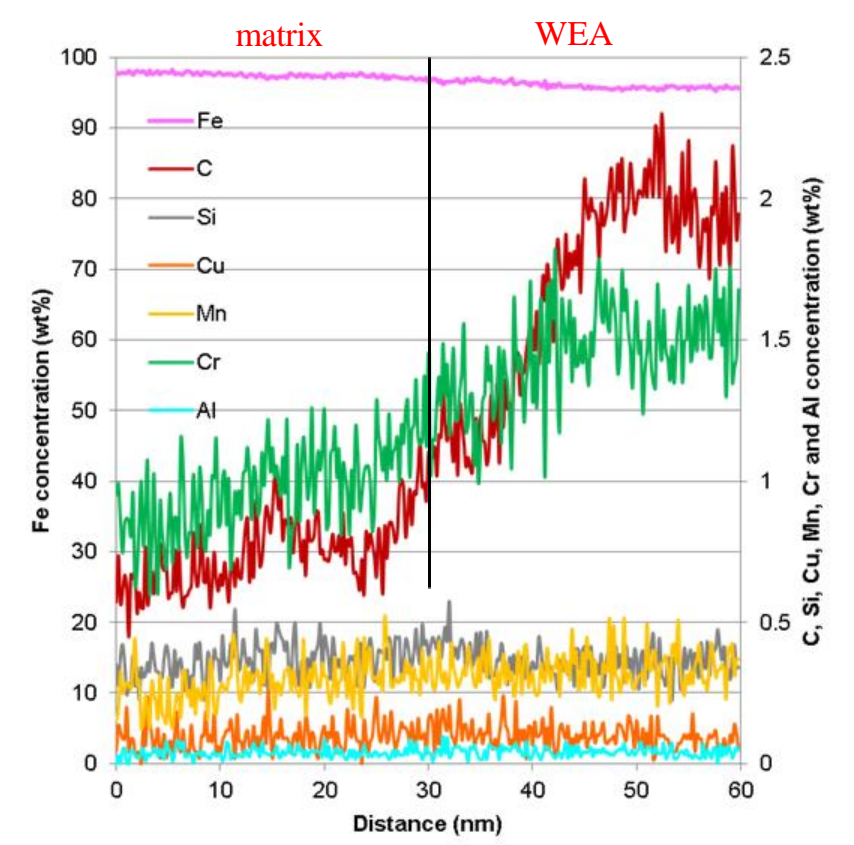

(c) Distribution of the detected chemical compositions at boundary between matrix and WEA

Fig. 10 3DAP quantitative analysis of chemical compositions 
母相と WEA の境界より $25 \mathrm{~nm}$ 母相内における平均的な C 濃度は $0.66 \mathrm{wt} \%$ ありり, $\mathrm{Cr}$ 濃度は $0.87 \mathrm{wt} \%$ なって いる. それに対して母相と WEA の境界より $25 \mathrm{~nm}$ WEA 内においては, C 濃度 $2.0 \%, \mathrm{Cr}$ 濃度 $1.5 \%$ なっている。

一方，境界より離れた母相の C 濃度は $0.7 \%, \mathrm{Cr}$ 濃度は $0.8 \%$ となっており，WEAの C 濃度は $1.4 \mathrm{wt} \%, \mathrm{Cr}$ 濃度は 1.6wt\%となっている. WEA の C と Cr の濃度は母相よりも高くなっている. 境界における $\mathrm{C} と \mathrm{Cr}$ 濃度の急激な 変化は図 2 の母相と WCA の境界が明瞭な形態と対応している. なお, 図 $10(\mathrm{c})$ において $\mathrm{Cu}$ と $\mathrm{Al}$ が検出されてい るが，Cuと Al は鋼中に含まれる化学成分であり，3DAPのような高精度な分析を行った結果として不可避的に 検出されたものである. $\mathrm{Cu}$ は天然同位体比より, $\mathrm{Al}$ は他の原子・分子との質量干涉の観点から検討し, 検出さ れても不自然ではないとの結果が得られている.

\section{3-6.2 はく離面の WEA}

はく離面で観察された WEA の OM 写真を図 11(a)に示し，図 11(b)に 3DAP を用いて分析を行った分析箇所を 示す. 母相と WEA の 2 か所である. 母相と WEA における全原子の 3 次元原子像と C のみの 3 次元原子像の 1 例を図 12 に示す. なお, 母相の場合, 先端付近に $\mathrm{Ga}$ ダメージによる酸化領域が認められる. 母相の $\mathrm{C}$ 濃度は $0.4 \mathrm{wt} \%, \mathrm{Cr}$ 濃度は 1.1wt\%となっており, WEA の C 濃度 $2.0 \mathrm{wt} \%, \mathrm{Cr}$ 濃度は $1.6 \mathrm{wt} \%$ となっている. この 3 次元原 子像や分析結果より，分析した試験片内に炭化物を含んでいないことは明らかである. $3 \cdot 6 \cdot 1$ に示したはく離 付近の化学成分の分析結果と同様な結果が得られている.

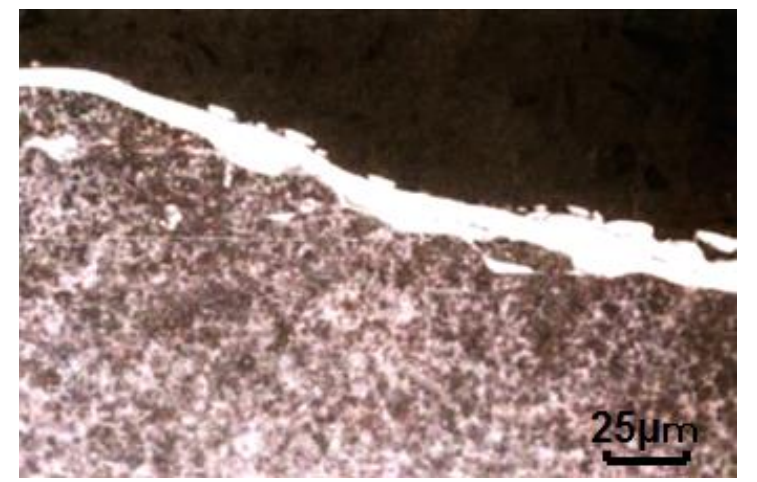

(a) Optical microscope photo of high magnification

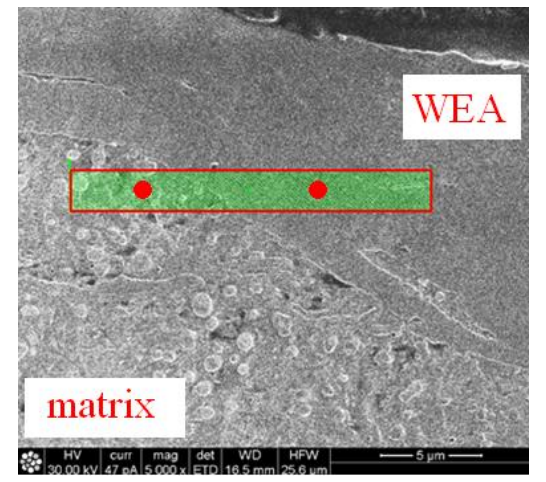

(b) Positions of 3DAP analysis

Fig. 11 WEA of 3DAP analysis

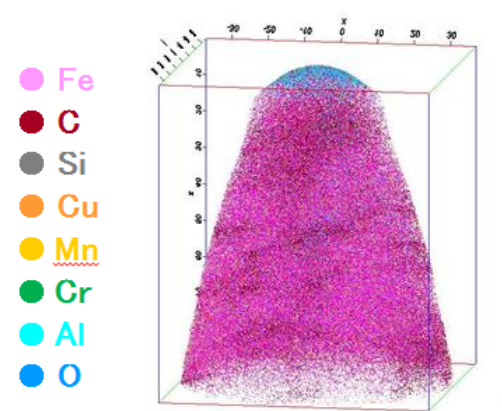

the detected chemical compositions

(a) matrix

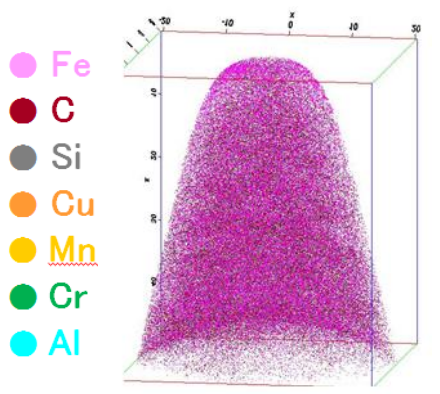

the detected chemical compositions

(b) WEA

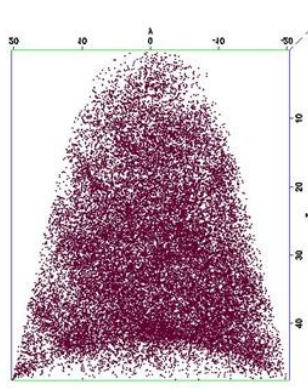

the detected carbon

Fig. 12 Three-dimensional image using 3DAP 


\section{$3 \cdot 6 \cdot 3$ 母相と WEA の境界付近における C 濃度と $\mathrm{Cr}$ 濃度の分布}

$3 \cdot 6 \cdot 1$ と $3 \cdot 6 \cdot 2$ の結果を合せた C 濃度分布と Cr 濃度分布を図 13 に示寸. 横軸は母相と WEA の境界から の距離を示すが，何点か隣接して測定している場合にはその平均位置を境界からの距離として図化した.

$\mathrm{C}$ 濃度の平均值は母相で $0.59 \mathrm{wt} \%, \mathrm{WEA}$ で $1.8 \mathrm{wt} \%$ であり, Cr 濃度の平均值は母相で $0.92 \mathrm{wt} \%, \mathrm{wEA}$ で $1.6 \mathrm{wt} \%$ であった。

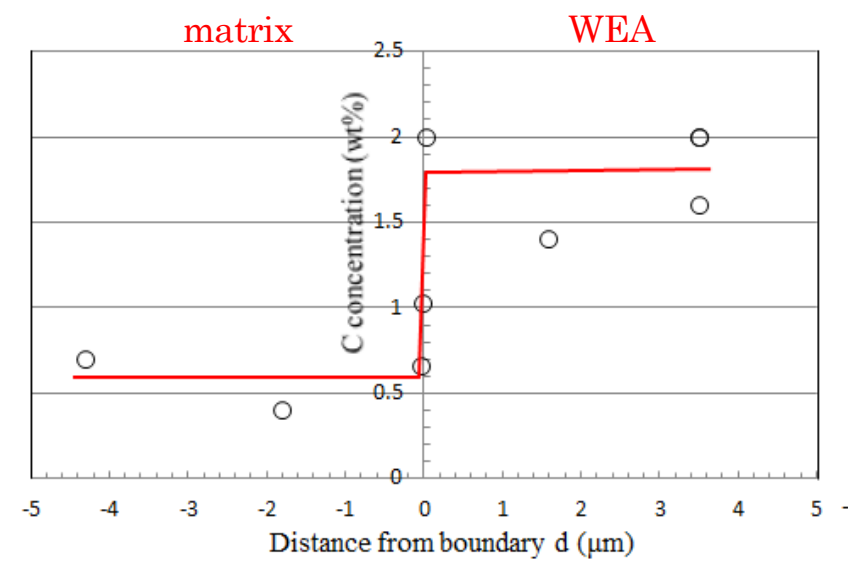

(a) Carbon

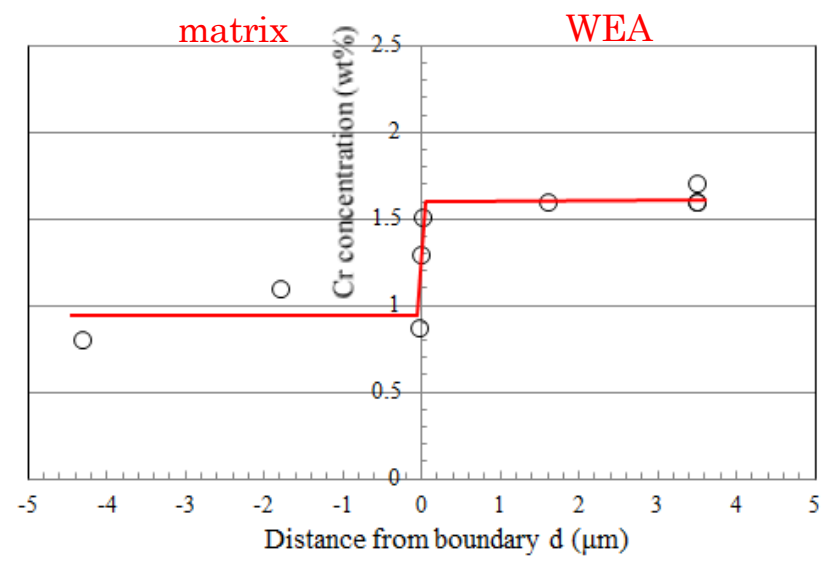

(b) Chromium

Fig. 13 Distribution of the detected chemical compositions at boundary between matrix and WEA

高炭素クロム軸受鋼 SUJ2 の場合, 残存炭化物量によっても母相の C 濃度と Cr 濃度が異なると過去に報告され ている（仕幸他，1968，瀬戸，1999）。この報告結果と図 11(b)の球状炭化物の粒径をもとにすると，母相のC 濃 度は約 $0.5 \mathrm{wt} \%, \mathrm{Cr}$ 濃度は約 $1.0 \mathrm{wt} \%$ となり, 本研究の母相の C と Cr の濃度と近い值を示している. 一方, WEA 内では球状炭化物が消失していることより，C濃度と $\mathrm{Cr}$ 濃度は高炭素クロム軸受鋼の化学成分規格（JIS G 4805(1990) : C 濃度は 0.95 1.10wt\%，Cr 濃度は 1.30 1.60wt\%）程度になっている．但し， Cr 濃度は化学成分規 格の上限に近い值となっており，C濃度は化学成分規格の上限よりも増加した結果となっている。この結果から RCF 中の軌道面内部の繰返し応力によって C の拡散が起こっていることが示唆される. Cr の拡散の可能性も示 唆されるが，規格值範囲内であり不明確である，なお， Cr 濃度が大幅に増加した結果となっていなかったのは， $\mathrm{Cr}$ の拡散定数が C の拡散定数よりも小さいため（瀬戸，1999）と思われる.

図 8 に示した母相とWEA の主な化学成分の分布を図 14 に示寸. 針状の試験片の軸に対して垂直方向の面分析 結果である. 母相の C のコントラストの濃い領域は細長い形として存在しているのに対して，WEA のCのコン トラストの濃い領域は直径 10～20nm 程度の円形として存在しているようである．前者は焼戻しラスマルテンサ イト組織の微細組織に対応しているものと思われる，後者は，上記 $3 \cdot 4$ より， $\alpha$ - Fe（フェライト）の数 $10 \mathrm{~nm}$ 程 度の結晶粒径に対応しており, C が粒界付近に多く存在しているものと思われる. WEA の TEM 観察では $\alpha$-Fe ( エライト）中に析出物が確認されず，球状炭化物の分解で発生した C の大部分は粒界付近に偏析しているものと 思われる．なお，C以外の元素分布は母相とWEA ともに均一に分布している.

C が粒界付近に偏析しているおよび $\mathrm{Cr}$ が均一に分布している化学成分の分析結果は円筒ころスラスト軸受の レースの軌道面内部に生じた WEA の化学成分の分析結果と同様な結果が得られている（Danielsen et al., 2017）. 


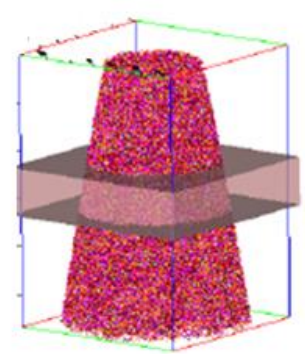

WEA

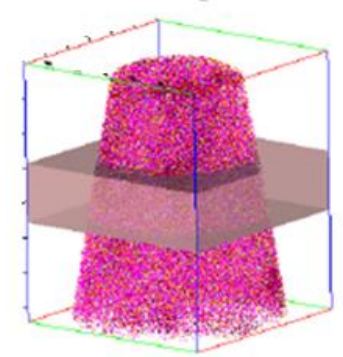

matrix

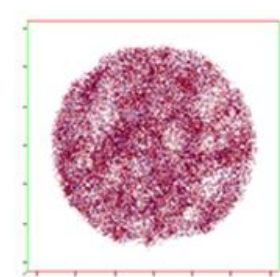

C

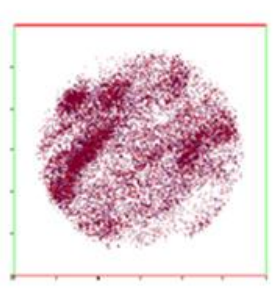

C

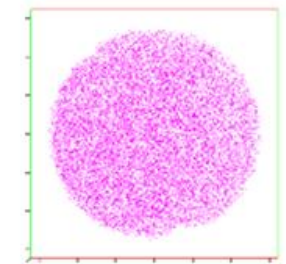

$\mathrm{Fe}$

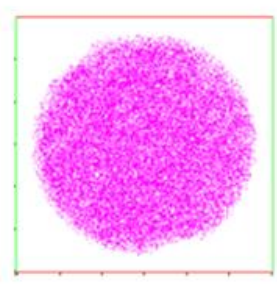

$\mathrm{Fe}$

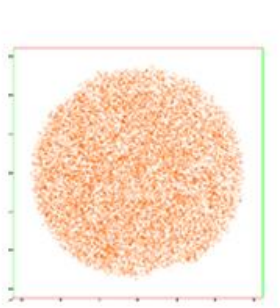

$\mathrm{Cr}$

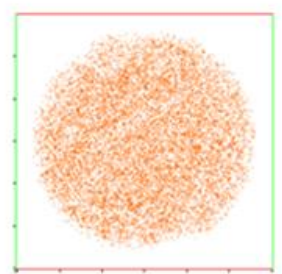

$\mathrm{Cr}$

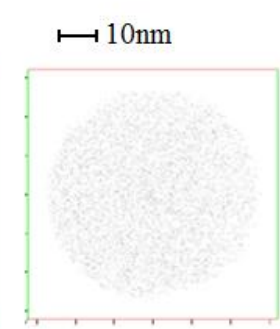

$\mathrm{Si}$

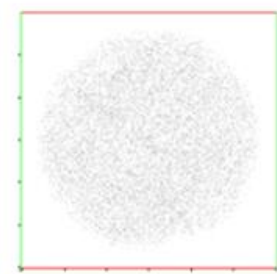

$\mathrm{Si}$

Fig. 14 Two-dimensional image using 3DAP

\section{4. 結 言}

深溝玉軸受のボールに発生した WEA をマクロからナノスケールの観察技術を用いて検討し, 以下の結果を得 た.

（1）ボールに生じた WEA の OM と SEM を用いた形態観察の結果およびEPMA を用いた化学成分の分析結果 は従来の内外輪軌道面内部に生じた WEA の形態の観察結果と化学成分の分析結果とほぼ同一である.

(2) TEM を用いた組織観察によれば，WEA は結晶粒径が数 $10 \mathrm{~nm}$ 程度のフェライト組織である．ボールに生 じた WEA の組織は従来の内外輪軌道面内部に生じた WEA の組織とほぼ同一である.

(3) 3DAP を用いた化学成分の分析結果によれば, ボールに生じた WEA は母相に比べて大幅にC 濃度が高く なっており, 結晶粒径が数 $10 \mathrm{~nm}$ 程度の $\alpha-\mathrm{Fe}$ (フェライト）の粒界に C が多く偏析している. 一方, $\mathrm{Cr}$, $\mathrm{Fe}, \mathrm{Si}$ は均一に分布している. この WEAの化学成分の分析結果は従来のレースの軌道面内部に生じた WEA の化学成分の分析結果と同様な結果が得られている.

なお，母相と WEA の境界における $\mathrm{C}$ と Cr 濃度の急激な変化は SEM で観察される母相と WEA の境界 が明瞭な形態と対応していることが明らかとなった。

\section{謝辞}

本研究を遂行するにあたり，東芝ナノアナリシス株式会社に3DAPによる分析を実施頂きました。ここに記し て心から感謝の意を表します。

\section{文献}

Bruce, T., Rounding, E., Long, H. and Dwyer-Joyce, R.S., Characterisation of white etching crack damage in wind turbine,

Wear, Vol.338-339(2015), pp.164-177. 
Danielsen, H.K., Guzmán, F.G., Dahl, K.V., Li, Y.J., Wu, J., Jacobs, G., Burghardt, G., Fæster, S., Alimadadi, H., Goto, S., Raabe, D. and Petrov, R., Multiscale characterization of white eching cracks(WEC) in a 100Cr6 bearing from a thrust bearing test rig. Wear, Vol.370-371(2017), pp.73-82.

平岡和彦，強ひずみ現象として見た転がり疲れによる白色型組織変化，鉄と鋼，Vol. 94, No. 12 (2008), pp. $636-643$. Ooi, S.W., Gola, A., Vegter, R.H., Yan, P. and Stadler, K., Evolution of white-etching cracks and associated microstructural alterations during bearing tests, Materials Science and Technology, Vol.33(2017), pp.1657-1666.

Richardson, A.D., Evance, M.-H., Wang, L., Wood, R.J.K., Ingram, M. and Meuth, B., The evolution of white etching cracks(WECs) in rolling contact fatigue-tested 100Cr6 steel, Tribology Letters(2018).

Ruellan, A., Kleber, X., Ville, F., Cavoret, J. and Liatard, B., Understanding white etching cracks in rolling element bearings : Formation mechanisms and influent tribochemical drivers, Journal of Engineering Tribology, Vol.229, No.8(2015), pp.886-901.

瀬戸浩蔵，軸受用鋼 20 世紀に生まれ、そして翔いた軸受用鋼，日本鉄鋼協会 (1999),pp.47-49, 157-173.

柴田正道，後藤将夫，小熊規泰，三上剛，エンジン・補機用軸受における転がり疲れによる新しいタイプの ミクロ組織変化, KOYO Engineering Journal, No.150(1996),pp.16-22.

仕幸三郎，岡本一生，渡辺章三，軸受鋼の寿命におよぼす熱処理組織の影響，鉄と鋼，Vol. 54, No. 13 (1968),pp.1353-1366.

Šmeļova, V., Schwedt, A., Wang, L., Holweger, W. and Mayer, J., Electron microscopy investigations of microstructural alterations due to classical rolling contact fatigue (RCF) in martensitic AISI 52100 bearing steel, International Journal of Fatigue,Vol.98(2017),pp.142-154.

Tamada, K. and Tanaka, H.,Occurrence of brittle flaking on bearings used for automotive electrical instruments and auxiliary devices, Wear, Vol.199(1996), pp.245-252.

植田光司，三田村宣晶，村上保夫，大堀學，転がり疲労に伴う材料の組織変化，材料とプロセス：日本鉄鋼協 会講演論文集, Vol. 15 (2002), pp. 1033-1036.

\section{References}

Bruce, T., Rounding, E., Long, H. and Dwyer-Joyce, R.S., Characterisation of white etching crack damage in wind turbine, Wear, Vol.338-339(2015), pp.164-177.

Danielsen, H.K., Guzmán, F.G., Dahl, K.V., Li, Y.J., Wu, J., Jacobs, G., Burghardt, G., Fæster, S., Alimadadi, H., Goto, S., Raabe, D. and Petrov, R., Multiscale characterization of white eching cracks(WEC) in a 100Cr6 bearing from a thrust bearing test rig. Wear, Vol.370-371(2017), pp.73-82.

Hiraoka,K. , White-type microstructural change in rolling contact fatigue from the viewpoint of severe plastic deformation, Tetsu-to-Hagane, Vol. 94, No. 12 (2008), pp. 636-643 (in Japanese).

Ooi, S.W., Gola, A., Vegter, R.H., Yan, P. and Stadler, K., Evolution of white-etching cracks and associated microstructural alterations during bearing tests, Materials Science and Technology, Vol.33(2017), pp.1657-1666.

Richardson, A.D., Evance, M.-H., Wang, L., Wood, R.J.K., Ingram, M. and Meuth, B., The evolution of white etching cracks(WECs) in rolling contact fatigue-tested 100Cr6 steel, Tribology Letters(2018).

Ruellan, A., Kleber, X., Ville, F., Cavoret, J. and Liatard, B., Understanding white etching cracks in rolling element bearings : Formation mechanisms and influent tribochemical drivers, Journal of Engineering Tribology, Vol.229, No.8(2015), pp.886-901.

Seto, K., Ball and roller bearing steels born and evolved in the $20^{\text {th }}$ Century, The Iron and Steel Institute of Japan (1999),pp. 47-49, 157-173 (in Japanese).

Shibata,M., Gotoh,M., Oguma,N. and Mikami,T. , A new type of microstructural change due to rolling contact fatigue on bearings for the engine auxiliary devices, KOYO Engineering Journal, No.150(1996), pp.16-22 (in Japanese).

Shiko,S., Okamoto,K. and Watanabe,S. , Effect of metallographical factors on the rolling fatigue life of ball bearing steel, Tetsu-to-Hagane, Vol. 54, No. 13 (1968), pp. 1353-1366 (in Japanese). 
Miyakawa, Nishimura, Nakazawa and Shioya, Transactions of the JSME (in Japanese), Vol.84, No.868 (2018)

Šmeļova, V., Schwedt, A., Wang, L., Holweger, W. and Mayer, J., Electron microscopy investigations of microstructural alterations due to classical rolling contact fatigue (RCF) in martensitic AISI 52100 bearing steel, International Journal of Fatigue,Vol.98(2017),pp.142-154.

Tamada, K. and Tanaka, H.,Occurrence of brittle flaking on bearings used for automotive electrical instruments and auxiliary devices, Wear, Vol.199(1996), pp.245-252.

Ueda,K., Mitamura,N., Murakami,Y. and Ohori,M. , Micro-structural changes due to rolling contact fatigue, Current advances in materials and processes : report of the ISIJ meeting, Vol. 15 (2002), pp. 1033-1036 (in Japanese). 